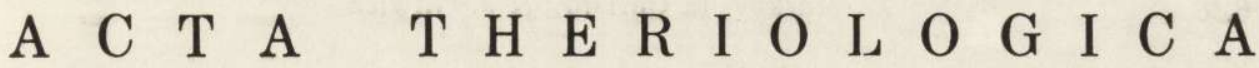 \\ VOL. XVII, 24: $327-335$. \\ BIAŁOWIEŻA \\ October, 1972
}

Georgij MARKOV, Lubomir CHR IST OV \& Joanna G L I W I C Z

\section{A Population of Clethrionomys glareolus pirinus on the Vitosha Mountain, Bulgaria. I. Variations in Numbers and Age Structure}

\author{
[With 2 Table \& 3 Figs.]
}

\begin{abstract}
Studies were made of a population of Clethrionomys glareolus in a spruce forest on Vitosha Mountain over a two-year period, by means of the Standard Minimum method, making two censuses per year (June, September). Variations in numbers were determined and changes in the population's age structure traced over the annual cycle.
\end{abstract}

\section{INTRODUCTION}

The International Biological Programme brought studies on the productivity of free-living populations, particularly of populations of dominating species of economic importance, or playing an important role in the life of ecosystems, to the forefront of ecological interest.

No studies of rodent populations have hitherto been carried out in Bulgaria. The present paper is the first attempt made at estimating density, age structure and variations in population numbers of Clethrionomys glareolus, $\mathrm{Schreber}, 1780$ - a species dominating in the higher parts of Vitosha Mountain. It has been made possible by co-operation between the Institute of Zoology, Bulgarian Academy of Sciences and the Institute of Ecology of the Polish Academy od Sciences on the problem of the "Biological productivity of terestrial ecosystems « under the International Biological Programme.

\section{AREA, MATERIAL, METHODS}

Investigations of a population of Clethrionomys glareolus pirinus Wolf, 1940, were carried out in a trapping areas of the "Bistrits « park on Vitosha Mountain with geographical co-ordinates $\mathrm{N} 23^{\circ} 25^{\prime}$ and $\mathrm{E} 42^{\circ} 30^{\prime}$, at an altitude of $1600 \mathrm{~m}$ 
above sea level, with a slope of $20-30^{\circ}$ to the north east, in an association of Piceetum myrtillosum in which Picea excelsa Lin k predominated, with occasional occurrence of Pinus silvestris L. and Fagus silvatica L. The undergrowth consists of Corrylus avellana L., Rubus idaeus L., Lonicera xyloteum L., and lower cover of Vaccinium myrtillus L. and Vaccinium vitis idaea L., and others. The ground is damp in spring and summer, dry in autumn and covered with snow in winter. The soil is of a brown forest type.

The Standard Minimum method (Grodziński, Pucek \& Ryszkowski, 1966) accepted for censusing small rodents was used. According to this method trapping was carried out in a square study area, measuring $240 \times 240 \mathrm{~m}$ and 5.76 hectares in area. It was divided into 16 rows and 16 lines perpendicular to each other placed at $15 \mathrm{~m}$ intervals, with a total number of 256 capture points. Each census lasted 10 days, during the first five days of which oats and sunflower seeds were placed on all of the 256 capture points and a check made every morning to see how much had been eaten (M arkov, Christov \& Gerasimov, 1968). During the following five days two snap traps of the "Hero" type were placed on each point, one of them baited with yellow cheese, the other with a fried wick.

During the 4 censuses made (June, September 1967, June, Semptember 1968) a total of 190 individuals of Clethrionomys glareolus were caught, and also 180 animals belonging to 5 other species (Table 1). Weight, sex, degree of sexual activity and

Table 1

List of species caught during the censuses.

\begin{tabular}{lrrrr}
\hline \multicolumn{1}{c}{ Species } & June, 1967 & Sept. 1967 & June, 1968 & Sept. 1968 \\
\hline$\quad$ Rodentia & 59 & 66 & 28 & 37 \\
Clethrionomys glareolus & 59 & 5 & 22 & 4 \\
Apodemus flavicollis & 16 & 6 & 3 & 8 \\
Pitymys subterraneus & 1 & & & 1 \\
$\begin{array}{l}\text { Glis glis } \\
\quad \text { Insectivora }\end{array}$ & & 46 & 10 & 53 \\
Sorex araneus & 4 & 46 & & 1 \\
Sorex minutus & & & & \\
\hline
\end{tabular}

age were defined for each individual of $C$. glareolus caught, then the animals were stored in $70 \%$ alcohol. In order to determine the animals' age the left $M_{1}$ was extracted in accordance with the method described by $\mathrm{Pucek} \& \mathrm{Zejda}$ (1968), steeping the jaws in $5-6 \% \mathrm{NaHCO}_{3}$ solution and then boiling them for 2 hours to facilitate extraction with tweezers.

The age of individuals of C. glareolus was determined on the basis of measurements of the average length of the oral and aboral root of $M_{1}$, made by means of binocular MBC-2 ocular-micrometer (magn. $2 \times$ ). The average monthly growth of a root was accepted as $0.15 \mathrm{~mm}$ after $\mathrm{Ze} \mathrm{j} \mathrm{d} \mathrm{a} \mathrm{(1961)} \mathrm{and} \mathrm{P} \mathrm{u} \mathrm{cek} \mathrm{\&} \mathrm{Zej} \mathrm{da} \mathrm{(1968).}$

\section{VARIATIONS IN NUMBERS, TAKING INTO CONSIDERATION THE AGE STRUCTURE OF INDIVIDUALS}

Analysis of the material in the authors' possesion showed that a number of additional calculations, with several assumptions, would have to 
be made in order to trace and discuss variations in numbers of the study population over the yearly cycle, particularly with respect to dynamics of different age classes. It was first of all necessary to: (1) estimate population numbers at the census times by the statistical method, since trapping by the Standard Minimum method used was far from intensive, especially in autumn; (2) estimate the population numbers in spring, during the period of lowest standing crop; (3) estimate the numbers of individuals belonging to the youngest age class in spring, as the class was poorly represented in spring captures.

\subsection{Population Numbers at Census Times}

The simplest way of estimating population numbers on the basis of results obtained by the trapping method, and thus by the Standard Minimum method, is to make use of straight regression ( $\mathrm{H}$ a y $\mathrm{n}$ e, 1949), but this method can only be used when a constant probability of individuals being caught is assumed throughout the whole trapping period. In the present material trapping results on different days indicated a slight tendency to decrease. The method of truncated distributions ( $\mathrm{J}$ a n i o n, Ryszkowski \& Wierzbowska, 1968), was therefore taken as a basis, which consideres the probability of an individual's capture varying from day to day. The number of individuals in the study area was estimated by means of the equation

$$
N=\frac{N_{1, K}}{1-q^{K}}
$$

where $N$ - numbers to be found, $N_{1, K}$ - total individuals caught during $K$ trapping days, $q=1-p$, where $p-$ probability of capture of an individual, $K$ - days of trapping.

The results of all 5 days of trapping were taken for calculation in the spring sample of 1967, and spring and autumn 1968, but the result of the 5 th day was rejected for the autumn sample 1967 as over-estimated, due to the intensive entry of individuals from neighbouring areas (Fig. 1). From the states of population numbers calculated by this method during the various censuses only the numbers from the autumn censuses were considered as reliable, since when analysing the age structure of individuals (see below) it was found that young individuals are poorly represented in material from spring censuses.

\subsection{Population Numbers at the Start of the Reproduction Season}

In order to obtain a picture of variations in population numbers over a period of two years it was necessary to estimate the standing crop of 
old adults at the start of the reproduction season when the population is low. April 1 was taken, after S te fa nov \& V a sil e v (1963), as the start of this period. Numbers of individuals on 1 April 1967 were estimated by extrapolating backwards variations in numbers of old adults from June to September 1967, obtaining the estimated figure of 43 individuals for this date.

Population numbers on 1 April 1968 were found by interpolating in a straight line the numbers for September 1967 and June 1968, obtaining a figure of 53 individuals. For 1 April 1969 the number of old adults (32)

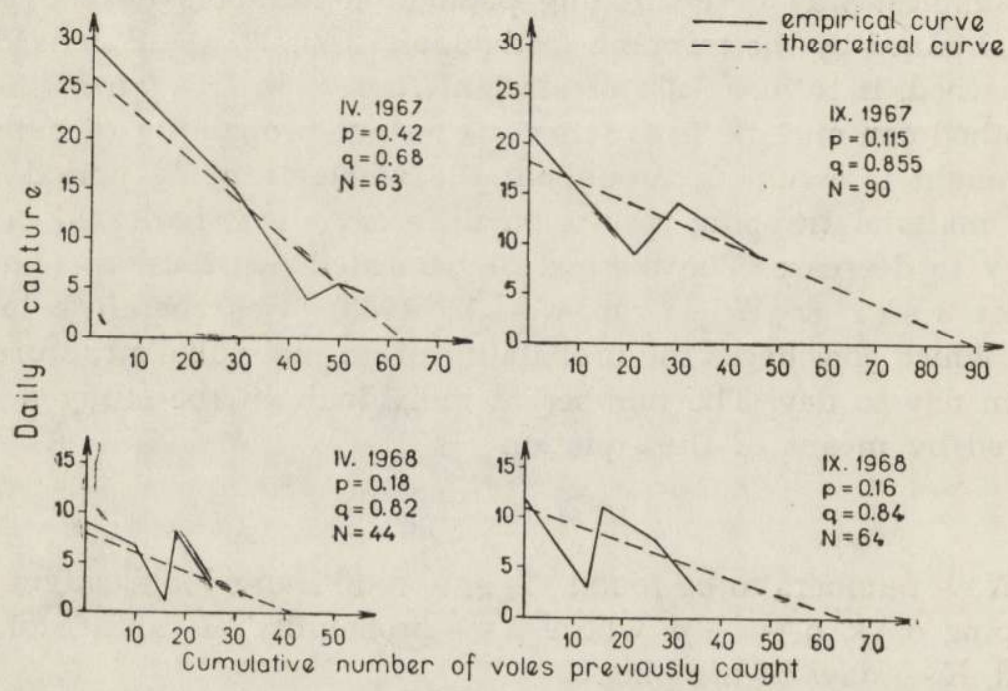

Fig. 1. Estimation of the number of individuals present in the area.

was estimated from the autumn numbers in 1968, assuming that mortality in the winter of $1968 / 1969$ was the same as in the preceding year. This same mortality was also assumed for estimating the numbers of individuals in the spring cohort $\left(K_{1}\right)$ during the June census.

\subsection{Variations of Numbers in Cohorts}

Definition of the age of individuals on the basis of growth of the roots of $M_{1}$ permitted distinguishing the following age groups among the individuals caught in successive censuses: below 3 months old, $3-5$ months, 6-8, 9-11, 12-14 and over 14 months old. Using the percentage of individuals in each age class in material obtained by trapping as 
a basis, the numbers in these classes were defined in an estimated standing crop of the population (Table 2).

In June $K_{1}$ individuals born between the start of the reproduction season and the June census belong to the first age group (under 3 months old) (Markov, Bujalska \& Christov, 1972). These individuals from the second group in September ( $3-5$ months old), and in the following spring belong to the oldest group (over 14 months old). Individuals born between spring and autumn censuses, forming cohort $K_{2}$ belong to the youngest group in September and in spring of the following year to the fifth group (from 12-14 months old). Finally, individuals in the last cohort, $K_{3}$ born between the end of the reproduction season, are not recorded during the year of their birth by the method used, and in spring of the following year they form the youngest group of overwintered animals (9-11 months old).

It is clear from material organized in this way (Table 2) that young individuals are poorly represented in the spring trappings. Fewer young

Table 2

Age structure of the population during the censuses.

\begin{tabular}{lcccccc}
\hline \multirow{2}{*}{ Censuses } & \multicolumn{7}{c}{ Age, months } \\
& $<3$ & $3-5$ & $6-8$ & $9-11$ & $12-14$ & 14 \\
\hline June, 1967 & $39+26^{*}$ & - & - & 8 & 13 & 3 \\
Sept., 1967 & 40 & 45 & - & - & 3 & 2 \\
June, 1968 & $16+15^{*}$ & - & - & 2 & 25 & 1 \\
Sept., 1968 & 45 & 14 & - & - & 3 & 2 \\
\hline
\end{tabular}

* Estimating numbers on the basis of census results underestimated the actual numbers and required additional calculation.

individuals were caught in spring 1967 than in autumn (then belonging to the second age group). This is confirmed by the number of individuals actually born in the same population in spring as estimeted by $\mathrm{M}$ a r $\mathrm{kov}$ et al. (1972). If the number of young obtained from S.M. methods were taken as reliable in spring, then mortality among these individuals from birth to first capture would be improbably high. Underestimation of the numbers of young based on the spring census is probably due to the fact that the young animals have less chance of being caught owing to the strong pressure exerted by old adults (G li w i c z, 1970).

In order to define variations in population numbers, the number of young animals in spring was calculated from data on mortality, and the result indicates that numbers of the whole population are higher in spring than estimations based on trapping. 


\subsection{Viability of Cohorts}

In order to illustrate cohort survival, the number born in each cohort and their mean birth dates (Markov et al., 1967) as well as mortality characters devised by G liw i c z et al. (1968), were utilized (Fig. 2). An estimate of the viability of $K_{3}$ individuals (not recorded during the year of their birth) was made on the basis of these data. Mortality of these animals from birth to day 21 was taken as equal to mortality among $K_{2}$

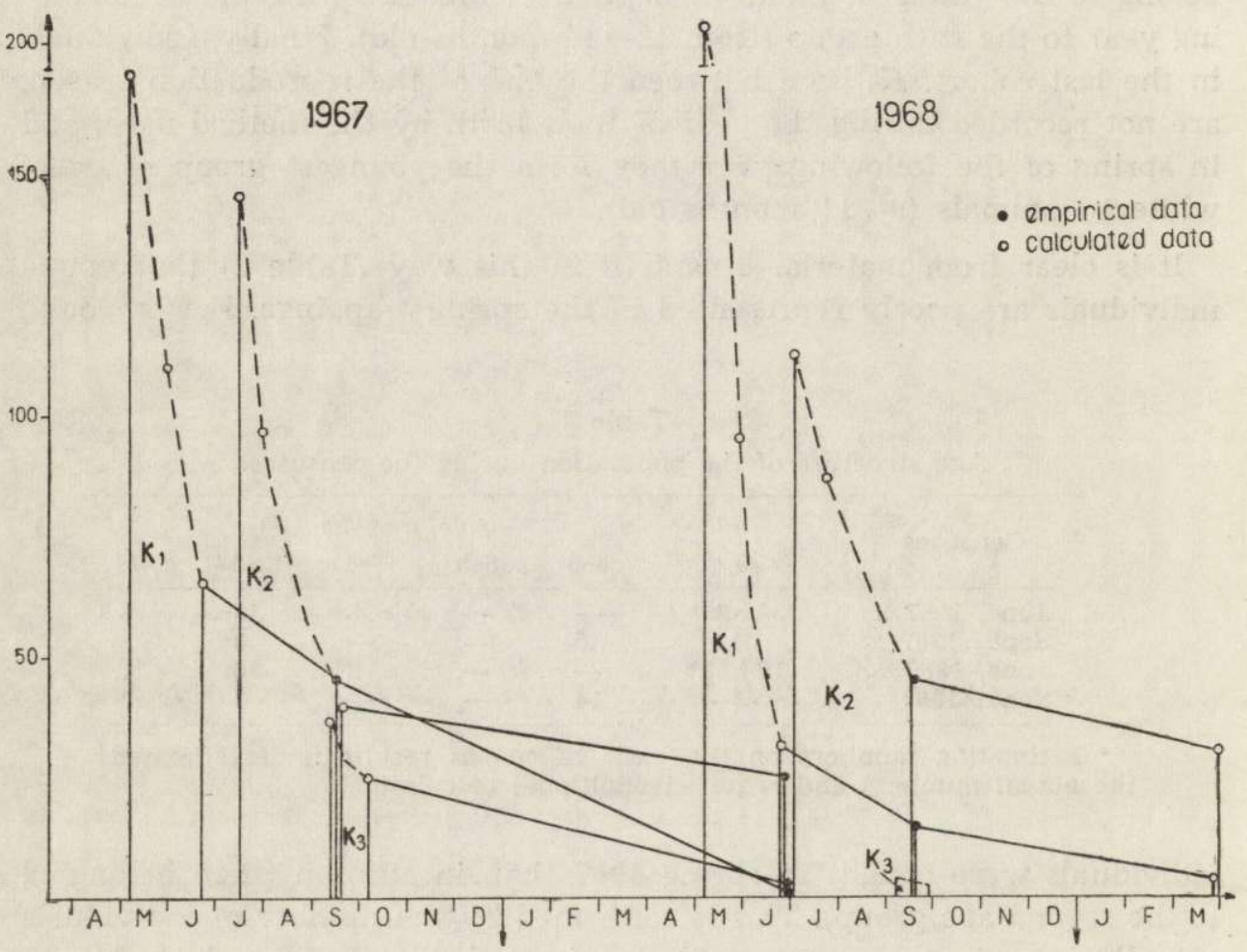

Fig. 2. Survival of individuals in different cohorts.

individuals. The number of individuals in each cohort was also estimated on day 21 this being assumed first day of independence from the nest.

On the basis of survival data of different cohorts from day 21 to the end of the study, a diagram was obtained of variations in numbers of this independently existing part of the population (Fig. 3). Those voles which were trappable but had not survived until census time and thus never caught are distinguishable on the diagram. 
The course taken by variations in numbers shows that the two study seasons differed slightly. The initial standing crop of the population in April 1967 and 1968 was similar, as was also the number of individuals born in the spring of both years, but, probably, due to the colder spring of 1968 , mortality of young was higher during this period. Hence the spring cohort was represented by fewer numbers in the trappable part of the population. This in turn reduced the number born in subsequent

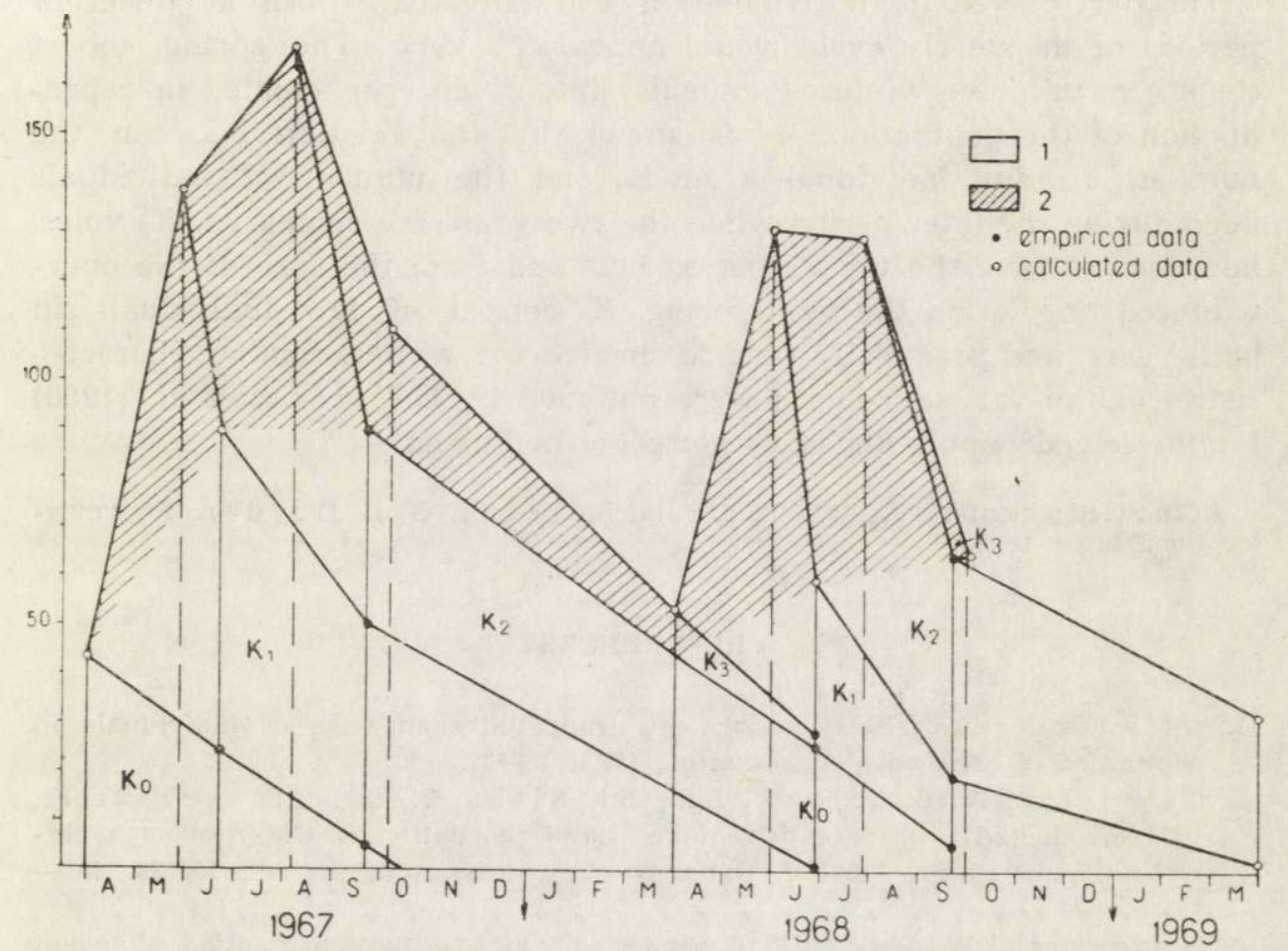

Fig. 3. Dynamics of the trappable part of the population.

1 - According to the corrected Standard Minimum, 2 - Individuals aged 21 days and not caught.

periods, since females of the spring cohort play a decisive role in the population, being intensively reproductive (Petrusewicz, Bujalska, Andrzejewski \& Gliwicz, 1971). In effect, population numbers in 1968 were lower than in 1967.

\section{DISCUSSION}

Under the conditions prevailing in a spruce forest on Vitosha Mountain, the Standard Minimum method used did not permit, due to poor trappability of the animals, accurately tracing variations in numbers of 
the study population on the basis of empirical data alone. The greatest difficulty was encountered in estimating the numbers of young individuals during the spring census and this made further assumptions necessary.

The estimated density of these voles varied during the study years from 7 and 9 individuals per hectare during early spring to 22 and 29 individuals during the autumn peak of abundance.

The part played in the population by individuals born at different periods of the yearly cycle would appear to vary. The spring cohort (together with overwintered animals) intensively participates in reproduction of the population, as is shown by the relation between the numbers of adult individuals from $K_{1}$ and the number of individuals born during the later period when the two years are compared. $K_{2}$ voles, however, survive the winter period best and form the core of the overwintered population the next spring. $K_{3}$ consist of few individuals in both years, and practically fails to survive the winter. Similar characteristics of the various cohorts were obtained by Gliwicz et al. (1968) for the island population of $C$. glareolus in Poland.

Acknowledgements: The authors are indebted to Dr. G. L. Dry de $\mathrm{n}$ for revising the English text.

\section{REFERENCES}

1. Gliwicz J., 1970: Relation between trappability and age of individuals in population of bank vole. Acta theriol., 15, 2: 15-32.

2. Gliwicz J., Andrzejewski R., Bujalska G. \& PetrusewiczK., 1968: Productivity investigation of an island population of Clethrionomys glareolus (S chreber, 1780). I. Dynamic of cohorts. Acta theriol., 13, 23: 401413.

3. Grodziński W., Pucek Z. \& Ryszkowski L., 1966: Estimation of rodent numbers by mean of prebaiting and intensive removal. Acta theriol., 11, 10: $297-314$.

4. H a y ne D. W., 1949: Two methods for estimating populations from trapping records. J. Mammal., 30: 399-411.

5. Janion M., Ryszkowski L. \& Wierzbowska T., 1968: Estimate of number of rodents with variable probability of capture. Acta theriol., 13: 285 $-294$.

6. Markov G., Bujalska G. \& Christov L., 1972: A population of Clethrionomys glareolus pirinus on the Vitosha Mountain, Bulgaria. II. Natality. Acta theriol., 17, 25: 337-342.

7. Markov G., Christov L. \& Gerasimov S., 1968: Rodent trapping with use of different kinds of bait. Small Mammal Newslett. 2, 3: 40-44.

8. Petrusewicz K., Bujalska G., Andrzejewski R. \& Gliwicz J., 1971: Productivity processes in an island population of Clethrionomys glareolus. Ann. zool. Fennici 8: 127-132. 
9. Pucek Z. \& Z e jda J., 1968: Technique for determining age in the red bank vole Clethrionomys glareolus (S chreber, 1780). Small Mammal Newslett. 2, 4: $51-60$.

10. Stefanov S. K. \& Vasilev V. I., 1963: Reproduction of bank vole (Clethrionomys glareolus Schreb.) on Vitosha mountain. Godiznik na Sof. Univ. 58: 35-53. [In Bulgarian].

11. Z e jda J., 1961: Age structure in population of bank vole, Clethrionomys glareolus (S c hre ber, 1780). Zool. Listy 10: 249-264.

Accepted, July 26, 1972.

Georgij Markov, Lubomir Christov, Institute of Zoology,

Bulgarian Academy of Sciences,

Sofia, Ruski 1, Bulgaria.
Joanna Gliwicz,

Institute of Ecology,

Polish Academy of Sciences,

Dziekanów n/Warszawa, Poland.

Georgij MARKOV, Lubomir CHRISTOV i Joanna GLIWICZ

POPULACJA CLETHRIONOMYS GLAREOLUS PIRINUS W LESIE SWIERKOWYM MASYWU WITOSZA W BUEGARII I. DYNAMIKA LICZEBNOSCI I STRUKTURA WIEKOWA

\section{Streszczenie}

W latach 1967-1968 badano populację Clethrionomys glareolus zamieszkującą las świerkowy na Witoszy. Badania prowadzono dwa razy do roku metodą Standard Minimum. Na podstawie wyników wyłowu (Tabela 1) oszacowano metodą rozkładów uciętych (Janion, Ryszkowski i Wierzbowska, 1968), liczebność populacji w badanych okresach (Ryc. 1). Wiek złowionych osobników określono przez pomiary długości korzenia $\mathrm{M}_{1}$ (P u cek i $\mathrm{Zej} \mathrm{da,} \mathrm{1968).} \mathrm{Analiza} \mathrm{roz-}$ kładu wiekowego osobników (Tabela 2) wykazała, że wyniki cenzusów wiosennych zaniżały liczebność populacji źle rejestrując osobniki młode. W konsekwencji liczebność populacji oszacowana na podstawie wyników wyłowu wiosennego wymagała skorygowania.

Przeanalizowano przeżywalność osobników należących do poszczególnych kohort tj. urodzonych w różnych okresach cyklu rocznego, opierając się na oszacowanej przez Markova, Bujalską i Christova (1972) liczbie osobników urodzonych oraz tempie ich ubywania pomiędzy kolejnymi cenzusami (Ryc. 2).

Prześledzono dynamikę liczebności łownej części badanej populacji w okresie 2 lat (Ryc. 3). Jej przebieg w obu latach byl nieco inny. 